\title{
Association of CTLA-4 Polymorphisms with Type 1 Diabetes in the Egyptian Population
}

Hatem Mohamed Saleh1, Bobby Koeleman², Gábor Szénási ${ }^{3,4}$, László Rosivall,4 and Peter Hamar³*

${ }^{1}$ The Egyptian Organization for Biological Products and Vaccines (EGYVAC-VACSERA), The Egyptian Ministry of Health and Population, Egypt ${ }^{2}$ Section Research, Department of Medical Genetics, University Medical Center Utrecht, The Netherlands

${ }^{3}$ Institute of Pathophysiology, Semmelweis University Medical School, Semmelweis University, Hungary

${ }^{4}$ Hungarian Academy of Sciences, Semmelweis University, Nephrology Research Group, Hungary

\begin{abstract}
Background: Polymorphisms in the cytotoxic T-lymphocyte antigen 4 (CTLA-4) are associated with the risk of type 1 diabetes (T1D). Here, we investigated the most associated variants CT60 and $+49 \mathrm{~A} / \mathrm{G}$ and five other putative promoter SNPs for their association with T1D in the Egyptian population, a multi-ethnic group. The comparison of disease association between populations can provide further evidence for putative disease variants.
\end{abstract}

Methods: Association of seven SNPs $(-1722,-1661,-651,-319,+49,-819$ and $+6230 \mathrm{G}>\mathrm{A})$ in the CTLA-4 gene with T1D was investigated in 396 patient and 396 control subjects of Egyptian origin. The diagnosis of T1D was made based on ketoacidosis or ketosis with acute onset and severe symptoms of diabetes mellitus at presentation and continuous dependence on insulin. Controls were negative for anti-GAD antibodies and were older than 24 years of age. Genotyping was performed using polymerase chain reaction-restriction fragment length polymorphism (PCR-RFLP).

Results: Five of the seven CTLA-4 gene SNPs were associated with T1D with the highest association for +49 A/G in exon $1(P=0.0002$; odds ratio: $1.6,95 \% \mathrm{Cl} 1.3-1.9)$. Association conditional on SNP +49 A/G was further tested, revealing some independent association for SNPs -1661 and -318 . Haplotype analysis of these SNPs demonstrated that no single haplotype was indicative of T1D risk.

Conclusion: The results further support the association of T1D with+49 A/G SNP in the CTLA-4 gene in the Egyptian population. The pattern of association specifically differed from that observed in European and other North African populations, providing further opportunity for fine mapping of genetic disease variants of type-I diabetes.

Keywords: CTLA-4; T1D; RFLP; Children; Egyptian; Race

\section{Introduction}

Type 1 diabetes (T1D) is a genetically complex disorder of glucose homeostasis caused by autoimmune mediated self-destruction of insulin-secreting cells of the pancreas. The disease is thought to be the result of exposure to environmental factors combined with genetic susceptibility that contribute to the development of T1D in a complex manner [1]. To date, genetic predisposition to T1D has been associated to more than 20 confirmed genetic loci [2].

The strongest risk for T1D is conferred by the major histocompatibility complex, class II, DQ beta 1 gene (HLA-DQB1) also named as Insulin Dependent Diabetes Mellitus gene (IDDM1). It has been estimated that about $40 \%$ of heritable risk can be explained by IDDM susceptibility genes [3]. The Cytotoxic-T-lymphocyte antigen (CTLA-4, CD-152) encoding gene (IDDM12) is one of the most important non-HLA susceptibility genes of T1D and other autoimmune diseases. IDDM12 maps to chromosome 2q33 [4]. The role of CTLA-4 in the autoimmune process has been emphasized by its association with systemic lupus erythematosus, celiac disease, rheumatoid arthritis, and autoimmune thyroid diseases [5]. CTLA-4 is a receptor, that downregulates the immune response. The IDDM12 gene contains a cluster of Tlymphocyte-regulating genes including CTLA-4, CD28, and inducible T-cell co-stimulator (ICOS). CD28 and CTLA-4 are co-stimulatory receptors that together with the antigen specific T-cell receptor (TCR) bind the $\mathrm{B} 7$ family molecules on the surface of antigen presenting cells (APC). CD28 enhances whereas CTLA-4 inhibits T-cell proliferation. Binding of CTLA-4 to the B7 limits the proliferation of T-cells and terminates the ongoing immune response [6]. CTLA-4 knockout mice develop severe lymphoproliferative disorder; die within a few days after birth, highlighting the importance of this gene in the negative regulation of the immune response [7]. Recently, the susceptibility for T1D was remapped to the 3 'untranslated region (UTR) of the CTLA4 gene [8]. The previously implicated +49 and CT60 variants were confirmed to have the strongest association withT1D but the mapping of the causal variant remained ambiguous and did not exclude the possibility of association with multiple functional variants. Apart from re-sequencing, association of CTLA-4 variants in different populations is a strategy for further fine mapping. In general, the compelling data on the association of CTLA-4 polymorphisms with T1D is convincing in some populations including Belgian [4,9], French, Italian, Korean, Mexican, Spanish-American [10], Japanese [11-15], Chinese [16], Russian [17], British [18], Moroccan [19], Estonian [20], and Croatian [21] populations.

On the other hand, further studies found no association in Chinese

*Corresponding author: Peter Hamar, Institute of Pathophysiology, Semmelweis University Medical School Budapest, Semmelweis University, 1089, Nagyváradtér 4, Hungary, E-mail: hamar.peter@med.semmelweis-univ.hu

Received July 17, 2013; Accepted September 16, 2013; Published September 20, 2013

Citation: Saleh HM, Koeleman B, Szénási G, Rosivall L, Hamar P (2013) Association of CTLA-4 Polymorphisms with Type 1 Diabetes in the Egyptian Population. J Diabetes Metab 4: 291. doi:10.4172/2155-6156.1000291

Copyright: $\odot 2013$ Saleh HM, et al. This is an open-access article distributed under the terms of the Creative Commons Attribution License, which permits unrestricted use, distribution, and reproduction in any medium, provided the original author and source are credited. 
[10], Japanese [22-24], Czech [25], Iranian [26], Argentinean [27], Chilean [28], Portuguese [29] and Turkish [30] children.

These distinct association patterns in different populations may provide important clues to clarify the causal variants by exploiting recombination events in the past that may generate distinct CTLA4 haplotypes, whose frequencies may vary between races [31]. In this study, we investigated whether the seven most implicated Single Nucleotide Polymorphism (SNPs) of the CTLA-4 gene are associated with T1D in the Egyptian population.

\section{Materials and Methods}

\section{Patients and controls}

All individuals who participated in this study gave informed written consent. The study was approved by the Egyptian Bioethics Review Committee for Bioethics (BERD) VACSERA. Three hundred and ninety six unrelated patients with T1D from different governorates of Egypt were recruited consecutively. The diagnosis of T1D was based on ketoacidosis or ketosis with severe symptoms of acute onset at presentation and continuous dependence on insulin. Moreover, patients included in the study had a Glycated Hemoglobin (HbAlc) $\geq 8.5 \%[32,33]$.

All patients were non-obese and $\leq 14 \mathrm{yr}$ of age at enrolment. Patients were separated into two groups for statistical analysis: younger than $6 \mathrm{yr}$ of age (0-5 age group) and 6to $14 \mathrm{yr}$ of age (6-14 age groups).

Healthy individuals older than 24 years of age - as recommended by the DiaMond protocol [34], with normal blood glucose $(n=396)$ were selected randomly from the Egyptian population to serve as controls. This age restriction is placed on the controls to exclude subjects from the high-risk period of $0-14 \mathrm{yr}$ of age, during which T1D is most likely to develop [18]. None of the controls had a family history of T1D. A standardized medical history questionnaire was completed by all patients and controls (Table 1).

The diagnosis of T1D was confirmed by elevated anti-glutamic acid decarboxylase (GAD) antibodies and low C-peptide levels. In controls, anti-GAD antibodies were absent and C-peptide levels were within the reference range $(0.4-2.2 \mathrm{ng} / \mathrm{ml})$. Individuals who were suspected to have Maturity-Onset Diabetes of the Young (MODY) or Wolfram syndrome were excluded from the study.

\section{SNP genotyping}

Blood $(1 \mathrm{ml})$ was collected in EDTA-tubes, and the DNA was extracted by a salting out method [35]. The DNA was dissolved in 50 $\mu$ Tris-EDTA (20 mM Tris, 2 mM EDTA, pH 7.5) buffer and stored at $-20^{\circ} \mathrm{C}$ until use.

Genomic DNA was amplified using PCR with different primers (forward and reverse) as shown in Table 2. Reaction volume was $50 \mu \mathrm{l}$ :

\begin{tabular}{|c|c|c|}
\hline Patients & $\begin{array}{l}\text { All patients } \\
1-14 \text { years old }\end{array}$ & $\begin{array}{l}\text { Controls } \\
>24 \text { years old }\end{array}$ \\
\hline Number of Patients & 396 & 396 \\
\hline $\begin{array}{l}\text { Age (yrs) } \pm \text { Mean } \\
\text { Range }\end{array}$ & $\begin{array}{l}7.28 \pm 1.9 \\
1-14\end{array}$ & $\begin{array}{l}31.5 \pm 4.7 \\
25-39\end{array}$ \\
\hline Weight (kg) & $39.0 \pm 9.67$ & $75.4 \pm 11.22$ \\
\hline Sex, N (\%) & $\begin{array}{lc}\text { Female } & 198(50) \\
\text { Male } & 198(50)\end{array}$ & $\begin{array}{lc}\text { Female } & 198(50) \\
\text { Male } & 198(50)\end{array}$ \\
\hline $\begin{array}{l}\text { Glycated Hemoglobin (HbA1c) } \\
\text { (Mean } \pm \text { SD) }\end{array}$ & $9.7 \pm 1.45$ & $5.6 \pm 0.25$ \\
\hline
\end{tabular}

Table 1: Demographics of the Study for Egyptian Population.
$4 \mu \mathrm{l}$ DNA at $100 \mathrm{ng} / \mu \mathrm{l}, 25 \mu \mathrm{l}$ DreamTaq Green master mix (Fermentas, $\mathrm{Lu}), 3 \mu \mathrm{l}$ of each primer $(30 \mathrm{pmol} / \mu \mathrm{l})$, and $15 \mu \mathrm{l} \mathrm{H}_{2} \mathrm{O}$. Reaction conditions were carried out using a model PTC100 thermal cycler (M\&J research, Watertown, MA, USA)

Following a PCR reaction carried out at $94^{\circ} \mathrm{C}$ for $5 \mathrm{~min}$ followed by 35 cycles of $94^{\circ} \mathrm{C}$ for $30 \mathrm{~s}$. Finally two heating cycles were applied at ca. $50^{\circ} \mathrm{C}$ for 30 or 45 seconds and then $72^{\circ} \mathrm{C}$ for $30 \mathrm{sec}$ (Table 3). Next, $10 \mu \mathrm{l}$ PCR product from each sample was resolved in $2 \%$ agarose gel to check the PCR products at the given bp fragment (Table 3). Restriction fragment length polymorphism (RFLP) analysis was done using the restriction enzymes given (Table 3 ) in $20 \mu \mathrm{l}$ total volume by mixing: 10 $\mu \mathrm{l}$ of PCR product $+1.0 \mu \mathrm{l}$ restriction enzyme $+2.0 \mu \mathrm{l} 10 \mathrm{X}$ restriction enzyme's buffer $+7 \mu \mathrm{l}$ nuclease-free water. The mixture was incubated at the given temperatures (Table 3 ) for 1 hour. DNA fragments were resolved in $3.0 \%$ agarose gel visualized by Ethidium Bromide (EtBr) staining. The digested alleles yielded the fragments listed in Table 3.

\section{Statistical analysis}

Genotype and allele distribution differences between patients and controls were tested by the chi-squared test with Yates' continuity correction. Statistical significance was defined as $p<0.05$, when the calculated $\chi^{2}>3.841$ for 1 degree of freedom, and $\chi^{2}>5.991$ for 2 degrees of freedom. Hardy-Weinberg equilibrium (HWE) was tested by comparing the expected and observed genotypes in $2 \times 3 \chi^{2}$ tables. None of the SNPs in patient or control groups deviated from the HWE. Power calculation was used the Genetic Power Calculator (http://pngu. mgh.harvard.edu/ purcell/gpc/) [36]. Our sample had sufficient power $(80 \%)$ to detect significant association of the studied SNPs for Odds ratios (OR) ranging between 1.6 and 1.05 for minor allele frequencies of 0.07 till 0.48 , respectively, assuming a co-dominant model of inheritance as has been suggested for CTLA-4. OR calculation, haplotypes and conditional analysis were calculated using the statistical program Unphased (https://sites.google.com/site/fdudbridge/software/) [37], which uses a logistic regression model to estimate effect sizes that are expressed as Ors [37]. The method is equivalent to calculating ORs and corresponding confidence intervals from $2 \times 2$ tables using the WoolfHaldane's method [38]. Adjustments to the level of significance were made for multiple analyses by Bonferroni correction of 7 independent tests [39].

\section{Results}

In the present study, we analyzed seven SNPs spanning the entire DNA sequence of the CTLA-4 gene for association with T1D using a case/control study of an Egyptian population. All controls were negative for anti-GAD antibodies and were $25 \mathrm{yr}$ of age or older. Furthermore, no control had a family history of T1D (Table 1).

Genotype and allele distributions of the seven SNPs were tested for association with disease status (Tables 4 and 5). We observed significant association after correction for multiple testing for SNPs $-1722,-1661,+49$ A/G, -819 , and CT60. The +49 A/G SNP had the strongest influence on disease state. Therefore, we proceeded to test all SNPs for independent association conditional on $+49 \mathrm{~A} / \mathrm{G}$, and vice versa, $+49 \mathrm{~A} / \mathrm{G}$ conditional on all other SNPs (Table 6). This analysis demonstrated a $+49 \mathrm{~A} / \mathrm{G}$ independent association of SNPs -1661 and -318 with T1D. Furthermore, evidence of +49 A/G independent associations were found for all other investigated SNPs except SNP $-318$

\section{SNP haplotype analysis}

The observation that the association of $+49 \mathrm{~A} / \mathrm{G}$ had a stronger 
Citation: Saleh HM, Koeleman B, Szénási G, Rosivall L, Hamar P (2013) Association of CTLA-4 Polymorphisms with Type 1 Diabetes in the Egyptian Population. J Diabetes Metab 4: 291. doi:10.4172/2155-6156.1000291

Page 3 of 6

\begin{tabular}{|c|c|c|c|c|}
\hline No & SNP Name & Forward primer & Reverse Primer & Alleles registered in $\mathrm{NCBI}$ \\
\hline 1 & $-1722 \mathrm{C}>\mathrm{T}$ & 5'CAAGCTTTGTCCTGTGACCA3' & 5'AAGCGCCAACAAGCATAAC3' & $\begin{array}{l}\text { FJ013949 } \\
\text { FJ013950 }\end{array}$ \\
\hline 2 & $-1661 A>G$ & 5'GCCACTGCTGTGTGTTCCT3' & 5'ATGTGCCTGTTGGTGTGAT3' & $\begin{array}{l}\text { FJ013951 } \\
\text { FJ013952 }\end{array}$ \\
\hline 3 & $-651 C>T$ & 5'TCCTTCTGCAAAACCAGAGGCAGCT3' & 5'AGTACAAGGGTCCTCCTAAATCCCA3' & $\begin{array}{l}\text { GQ370246 } \\
\text { GQ370247 }\end{array}$ \\
\hline 4 & $-318 \mathrm{C} / \mathrm{T}$ & 5'-AAGGATGCCCAGAAGATTGA3' & 5'AGCCGTGGGTTTAGCTGTTA3' & $\begin{array}{l}\text { Q390244 } \\
\text { Q390245 }\end{array}$ \\
\hline 5 & $+49 A>G$ & 5'-AAGGCTCAGCTGAACCTGGT-3' & 5'CTGCTGAAACAAATGAAACCC3' & $\begin{array}{l}\text { DQ534199 } \\
\text { DQ534200 }\end{array}$ \\
\hline 6 & $-819 C>T$ & 5'GGAGAGGGGCCTGGTTAGTTACA3' & 5'AGAGAGGCAGCGGTG GTGTCA3' & $\begin{array}{l}\text { EU103999 } \\
\text { EU104000 }\end{array}$ \\
\hline 7 & CT60 $(+6230 G>A)$ & 5'-CACCACTATTTGGGATATACC-3' & 5’AGGTCTATATTTCAGGAAGGC3' & $\begin{array}{l}\text { GQ370006 } \\
\text { GQ370007 }\end{array}$ \\
\hline
\end{tabular}

Table 2: The primers used in PCR-RFLP technique for genotyping the SNPs of CTLA-4 in this study.

\begin{tabular}{|c|c|c|c|c|c|c|c|}
\hline & $-1722 C>T$ & $-1661 A>G$ & $-651 \mathrm{C}>\mathrm{T}$ & $-318 C>T$ & $+49 A>G$ & $-819 C>T$ & $+6230 \mathrm{G}>\mathrm{A}(\mathrm{CT} 60)$ \\
\hline Temp $1\left({ }^{\circ} \mathrm{C}\right)$ & 50.5 & 53 & 57.5 & 58 & 55 & 62 & 59 \\
\hline Duration 1 (s) & 45 & 30 & 30 & 30 & 30 & 40 & 30 \\
\hline Temp $2\left({ }^{\circ} \mathrm{C}\right)$ & 72 & 72 & 72 & 72 & 72 & 72 & 72 \\
\hline Duration 2 (s) & 40 & 30 & 30 & 30 & 30 & 30 & 30 \\
\hline bp fragment & 398 & 214 & 330 & 212 & 152 & 180 & 216 \\
\hline Restriction enzyme & APek1 & Dral & Aci1 & Tru1 & Ecor911 & CviKI-I & Ncol \\
\hline Source & NEB & $\mathrm{FL}$ & NEB & $\mathrm{FL}$ & $\mathrm{FL}$ & NEB & $\mathrm{FL}$ \\
\hline Incubation temp $\left({ }^{\circ} \mathrm{C}\right)$ & 37 & 65 & 37 & 65 & 37 & 37 & 65 \\
\hline Digested allele & $\mathrm{CC}$ & AA & $\mathrm{CC}$ & TT & AA & $\mathrm{CC}$ & AA \\
\hline Yielded fragments (bp) & 266,132 & 162 & 300 & 93,119 & 131 & 69,111 & 162 \\
\hline Digested allele & $\mathrm{TC}$ & $A G$ & $\mathrm{CT}$ & CT & $A G$ & CT & $A G$ \\
\hline Yielded fragments (bp) & $132,266,398$ & $52,162,214$ & 300,330 & $93,119,212$ & 131,152 & $69,111,180$ & $54,162,216$ \\
\hline Digested allele & $\mathrm{TT}$ & GG & TT & $\mathrm{CC}$ & GG & $\mathrm{TT}$ & GG \\
\hline Yielded fragments (bp) & 398 & 214 & 330 & 212 & 152 & 180 & 216 \\
\hline
\end{tabular}

Abbreviations: NEB: New England Biolabs, UK; FL: Thermo Fisher Scientific, Inc (Fermentas), USA

Table 3: Details of SNP genotyping.

\begin{tabular}{|c|c|c|c|c|c|c|c|}
\hline \multirow{2}{*}{$\begin{array}{l}\text { SNP (major/minor allele) } \\
-1722(T>C) \\
(\text { rs733618) }\end{array}$} & \multicolumn{2}{|c|}{ Cases (\%) } & \multicolumn{2}{|c|}{ Controls (\%) } & \multirow{2}{*}{$\begin{array}{l}\text { Pc-value } \\
\underline{0.0294^{*}}\end{array}$} & \multirow{2}{*}{$\begin{array}{l}\text { OR } \\
1.6\end{array}$} & \multirow{2}{*}{$\begin{array}{l}95 \% \mathrm{Cl} \\
1.2-2.1\end{array}$} \\
\hline & $669(84)$ & $123(16)$ & $710(90)$ & $82(10)$ & & & \\
\hline $\begin{array}{l}-1661(A>G) \\
(\text { rs4553808) }\end{array}$ & $503(64)$ & $289(36)$ & $574(72)$ & $218(28)$ & $\underline{0.0182^{*}}$ & 1.5 & $1.2-1.9$ \\
\hline $\begin{array}{l}-651(\mathrm{C}>\mathrm{T}) \\
(\mathrm{rs11571318)}\end{array}$ & $714(90)$ & $78(10)$ & 736 (93) & $56(7)$ & $\underline{0.658}$ & 1.4 & $1.0-2.1$ \\
\hline $\begin{array}{l}-318(C>T) \\
\text { (rs5742909) }\end{array}$ & 717 (91) & $75(9)$ & $743(94)$ & $49(6)$ & $\underline{0.21}$ & 1.6 & $1.1-2.3$ \\
\hline $\begin{array}{l}+49(A>G) \\
(r s 231775)\end{array}$ & $498(63)$ & $294(37)$ & $576(73)$ & $216(27)$ & 3.724E-04* & 1.6 & $1.3-1.9$ \\
\hline $\begin{array}{l}-819 \text { (C>T) } \\
(\mathrm{rs} 231726)\end{array}$ & $540(68)$ & $252(32)$ & $592(75)$ & $200(25)$ & $\underline{0.0532}$ & 1.4 & $1.1-1.7$ \\
\hline $\begin{array}{l}\text { CT60 } \\
(+6230 G>A) \\
(\text { rs3087243) }\end{array}$ & 347 (44) & $445(56)$ & 409 (52) & $383(48)$ & $\underline{0.0252^{*}}$ & 1.4 & $1.1-1.7$ \\
\hline
\end{tabular}

The table shows counts and percentages between brackets of the alleles of seven CTLA-4 SNPs studied. P-value (Pc) is corrected for multiple testing of seven SNPs. Odds Ratio (OR) and corresponding 95\% confidence intervals are given for the minor allele

Table 4: Allelic association.

influence on T1D outcome than CT60 may indicate different CTLA4 haplotypes in the Egyptian population. Therefore, the pattern of LD and CTLA-4 haplotypes in the Egyptian sample was calculated. In order to test LD between SNPs typed, the D' values among seven SNPs were calculated using the estimated haplotype frequencies. All SNP combinations had a high absolute value of D' except the combination of -651 with-319 SNPs. This observation may explain the lower association of these two SNPs with T1D. To further investigate this, all possible CTLA-4 haplotypes of all seven SNPs were calculated
(Table 7). This analysis showed thirty three different haplotypes in 396 Egyptian patients. The TACCACG haplotype (where the nucleotide is indicated for each of the seven SNPs, as shown in Table 7) was the most frequent in the Egyptian population $(22.9 \%$ vs. $30.8 \%$ in cases and controls respectively). This haplotype was treated as the "wild type' or reference haplotype. Odds Ratio's of all other haplotypes were consequently calculated against this reference. As expected from the single SNP analysis, most haplotypes occurring more frequently in cases as compared to controls carried the susceptible G-allele at +49 
Citation: Saleh HM, Koeleman B, Szénási G, Rosivall L, Hamar P (2013) Association of CTLA-4 Polymorphisms with Type 1 Diabetes in the Egyptian Population. J Diabetes Metab 4: 291. doi:10.4172/2155-6156.1000291

Page 4 of 6

A/G. Interestingly, the most frequent haplotype carrying a G-allele at +49 A/G (haplotype TACCGCA) did not confer risk. Significantly increased risk relative to the wild type haplotype was found for six haplotypes of which two were carrying the A-allele at $+49 \mathrm{~A} / \mathrm{G}$.

These analyses demonstrated that the combination of these SNPs tag the undetected causal variant in a more efficient way than the single SNPs, confirming previous fine mapping studies.

\section{Discussion}

Genetic mapping of causal variants of susceptibility genes for complex diseases such as T1D remains complicated. Several aspects may be responsible for this complexity. First, each gene variant accounts for only a small proportion of susceptibility, necessitating large samples to acquire sufficient power for dissection of the association signal Furthermore, the association signal may be caused by multiple causal variants causing synthetic association [37]. Furthermore, conflicting

\begin{tabular}{|c|c|c|c|c|c|c|c|}
\hline \multirow{2}{*}{$\begin{array}{l}\text { SNP (genotype) } \\
-1722 \text { (TT/TC/CC) }\end{array}$} & \multicolumn{3}{|c|}{ Cases (\%) } & \multicolumn{3}{|c|}{ Controls (\%) } & \multirow{2}{*}{$\begin{array}{c}\text { P-value } \\
\underline{0.084} \\
\end{array}$} \\
\hline & $282(71)$ & $105(27)$ & $9(0.03)$ & $318(0.80)$ & $74(19)$ & $4(1)$ & \\
\hline-1661 (AA/AG/GG) & $159(40)$ & $185(47)$ & $52(13)$ & $208(53)$ & $158(40)$ & $30(7)$ & $\underline{0.0098^{*}}$ \\
\hline-651 (CC/CT/TT) & $318(80)$ & $78(20)$ & $0(0)$ & $343(86)$ & $50(13)$ & $3(1)$ & $\underline{0.112}$ \\
\hline-318 (CC/CT/TT) & $325(82)$ & $67(17)$ & $4(1)$ & 347 (88) & $49(12)$ & $0(0)$ & $\underline{0.84}$ \\
\hline 49 (AA/AG/GG) & $157(40)$ & $184(46)$ & $55(0.14)$ & $211(53)$ & $154(39)$ & $31(8)$ & $\underline{0.0028 *}$ \\
\hline$-819(\mathrm{CC} / \mathrm{CT} / \mathrm{TT})$ & $181(46)$ & $178(45)$ & $37(9)$ & $214(54)$ & $164(41)$ & $18(5)$ & $\underline{0.098}$ \\
\hline +6230 (AA/AG/GG) & $76(19)$ & $195(49)$ & $125(32)$ & $107(27)$ & $195(49)$ & $94(24)$ & $\underline{0.112}$ \\
\hline
\end{tabular}

The table shows counts and percentages between brackets of the genotypes of seven CTLA-4 SNPs studied.

P-values are corrected for multiple testing of seven SNPs

Table 5: Genotype association.

\begin{tabular}{|l|l|l|}
\hline Table 3. SNPv & p-value of SNP conditional on 49A/G & p-value of 49 A/G conditional on SNP \\
\hline$-\mathbf{1 7 2 2}$ & 0.8 & 0.0002 \\
\hline $\mathbf{- 1 6 6 1}$ & 0.005 & 0.001 \\
\hline $\mathbf{- 6 5 1}$ & 0.3 & 0.0002 \\
\hline $\mathbf{- 3 1 8}$ & 0.0008 & 0.11 \\
\hline $\mathbf{8 1 9}$ & 0.01 & $9.50 \mathrm{E}-05$ \\
\hline $\mathbf{+ 6 2 3 0}$ & 0.09 & 0.002 \\
\hline
\end{tabular}

The table shows Bonferroni corrected p-values for conditional testing of each SNP conditional on +49 A/G SNP (first column), and of +49 A/G SNP conditional on each SNP (second column)

Table 6: Results of test of conditional association

\begin{tabular}{|c|c|c|c|c|c|c|c|c|c|c|c|c|}
\hline Haplotype & Case & Control & Ca-Freq & Co-Freq & Ca-D' & Ca-r ${ }^{2}$ & Co-D' & Co- $r^{2}$ & Odds-R & 95\%Lo & $95 \% \mathrm{Hi}$ & Pc \\
\hline TACCACG & 181 & 244 & $22.9 \%$ & $30.8 \%$ & 0.8825 & 0.03714 & 0.9021 & 0.04237 & 1 & 1 & 1 & \\
\hline TGCCACA & 64 & 78 & $8 \%$ & $9.8 \%$ & -0.009883 & $7.75 e-5$ & -0.03606 & 0.001167 & 1.11 & 0.76 & 1.62 & \\
\hline TACCGCA & 59 & 108 & $7.4 \%$ & $13.6 \%$ & 1 & 0.01344 & 1 & 0.01829 & 0.74 & 0.51 & 1.07 & \\
\hline TACCATA & 52 & 80 & $6.5 \%$ & $10.1 \%$ & 1 & 0.01227 & 1 & 0.01291 & 0.88 & 0.59 & 1.31 & \\
\hline CGCCGCA & 41 & 34 & $5.2 \%$ & $4.3 \%$ & 1 & 0.4007 & 1 & 0.384 & 1.63 & 1.00 & 2.67 & \\
\hline TGCCATG & 41 & 33 & $5.2 \%$ & $4.2 \%$ & -0.02038 & 0.000205 & 0.5242 & 0.001439 & 1.68 & 1.03 & 2.76 & \\
\hline TACCGCG & 31 & 6 & $3.9 \%$ & $0.76 \%$ & 1 & 0.01066 & 1 & 0.000914 & 6.28 & 2.62 & 15.06 & 0.00003 \\
\hline TACCACA & 22 & 28 & $2.8 \%$ & $3.5 \%$ & -0.002983 & $2.422 e-6$ & 0.6362 & 0.001765 & 1.09 & 0.61 & 1.95 & \\
\hline TACCATG & 21 & 5 & $2.7 \%$ & $0.6 \%$ & 1 & 0.004763 & 1 & 0.0007987 & 4.65 & 1.84 & 11.76 & 0.004 \\
\hline TGCCGCG & 19 & 17 & $2.4 \%$ & $2.1 \%$ & -0.1551 & 0.005829 & 0.179 & $8.718 e-5$ & 1.50 & 0.76 & 2.95 & \\
\hline TACTGTG & 19 & 1 & $2.4 \%$ & $0.13 \%$ & 1 & 0.004202 & 1 & $9.68 e-5$ & 15.76 & 2.44 & 101.70 & 0.00007 \\
\hline TATCACA & 16 & 29 & $2 \%$ & $3.7 \%$ & 1 & 0.003412 & 1 & 0.00432 & 0.76 & 0.40 & 1.43 & \\
\hline TACTGCA & 14 & 0 & $1.8 \%$ & $0 \%$ & 1 & 0.003412 & 1 & 0.00432 & 16.04 & 1.61 & 159.83 & 0.0007 \\
\hline CGCCGTG & 13 & 20 & $1.6 \%$ & $2.5 \%$ & 1 & 0.005063 & 1 & 0.004677 & 0.87 & 0.43 & 1.79 & \\
\hline TACCGTA & 12 & 2 & $1.5 \%$ & $0.25 \%$ & 1 & 0.1223 & 0.7455 & 0.1629 & 6.99 & 1.56 & 31.37 & 0.02 \\
\hline TATCATG & 11 & 15 & $1.4 \%$ & $1.9 \%$ & 1 & 0.002475 & 1 & 0.002209 & 1.03 & 0.47 & 2.26 & \\
\hline TATCATA & 10 & 2 & $1.3 \%$ & $0.25 \%$ & 1 & 0.002279 & 1 & 0.0002206 & 5.82 & 1.29 & 26.19 & \\
\hline CGCCACA & 10 & 12 & $1.3 \%$ & $1.5 \%$ & 0.009883 & $7.75 e-5$ & 0.03606 & 0.001167 & 1.10 & 0.47 & 2.58 & \\
\hline TACTACA & 10 & 31 & $1.3 \%$ & $3.9 \%$ & 1 & 0.0025315 & 1 & 0.002338 & 0.46 & 0.22 & 0.96 & \\
\hline TGCCGTA & 9 & 5 & $1.1 \%$ & $0.6 \%$ & 1 & 0.001878 & 1 & 0.000662 & 2.32 & 0.77 & 7.04 & \\
\hline CGTCGTG & 7 & 7 & $0.9 \%$ & $0.9 \%$ & 0.6348 & 0.0373 & 0.7977 & 0.05621 & 1.36 & 0.47 & 3.92 & \\
\hline TACCGTG & 7 & 5 & $0.9 \%$ & $0.5 \%$ & 1 & 0.00137 & 1 & 0.0007303 & 1.73 & 0.56 & 5.34 & \\
\hline TACTATG & 0 & 13 & $0 \%$ & $1.6 \%$ & 1 & $5.987 e-13$ & 1 & 0.001956 & 0.10 & 0.01 & 1.61 & 0.05 \\
\hline Other & 123 & 17 & $15.5 \%$ & $2.1 \%$ & ------- & ------- & ------- & ------ & ----- & ------ & ------ & -------- \\
\hline
\end{tabular}

The table shows counts and percentages of estimated haplotypes. P-values (Pc) are corrected for 23 haplotype comparisons. Odds Ratio (OR) and corresponding 95\% confidence intervals are given, whereas Global D' for cases and controls are 0.7182 and 0.7922 , respectively

Table 7: Haplotypes of seven CTLA-4SNPs in the Egyptian T1D and control samples. 
results from different populations may be caused by certain mutations that may not exist in all racial/ethnic groups or geographical populations. Therefore, screening of hitherto uninvestigated populations may help elucidating genetic complexities [31].

We have previously investigated the prevalence of C-819T and A+49G SNPs of the CTLA-4 gene in male and female Egyptian children [40]. In the present paper we analyzed SNP associations and performed haplotyped analysis of 7 SNPs of the CTLA-4 Ig gene in T1D. This study confirmed association of five SNPs of the CTLA-4 gene with T1D in the Egyptian population and demonstrated that distinct susceptibility haplotypes exist in this patient cohort of Egyptian origin. The current analysis confirmed the association of CTLA-4 polymorphism with T1D in the Egyptian population. In contrast to previous fine mapping in European samples where the CT60 SNP had the strongest influence on disease state [8], in the present study, the strongest association mapped to the $+49 \mathrm{~A} / \mathrm{G}$ SNP located in the first exon and not to the more 3-prime region of the CTLA-4 gene. The +49 A/G SNP has been extensively studied in several ethnic populations of mostly European ancestry with conflicting results $[11,41,42]$. However, our haplotype analysis demonstrated that haplotypes not carrying the susceptible G-allele at $+49 \mathrm{~A} / \mathrm{G}$ were also detected in two susceptible haplotypes. This observation suggested that the $+49 \mathrm{~A} / \mathrm{G}$ were not the only variant influencing T1D. Conditional analysis further demonstrated that it is unlikely that either +49 or any of the other associated SNPs alone can be responsible for T1D risk. Rather a network of SNPs seems to have a prognostic relevance.

The pattern of LD and CTLA-4 haplotypes in the Egyptian sample was compared to previously published data of another North African population in Morocco. In comparison with the haplotypes found in Morocco, several differences illustrated the genetic diversity in this region. Bouqbis et al. published frequencies for four SNP haplotypes (SNPs -1722,-1661,-319 and +49) and reported that the TACA haplotype was the most frequent at $54.4 \%$ in the South Moroccan population [19]; similarly to the Egyptian population (54\%) in our study. Moreover, Bouqbis et al. reported that haplotype TGCA had the strongest association with T1D [19]. In our sample, this was clearly different regarding the -1661 and +49 SNPs: the TACG haplotype had the strongest association with T1D in the investigated Egyptian population. However, given the limited sample size of our study and that of Bouqbis et al. these differences could represent stochastic variation due to sampling error [19]. Our results do not confirm the absence of association of the $+49 \mathrm{~A} / \mathrm{G}$ variant in Egyptian population as in the West African and the Moroccan populations [18]. Therefore, the finding reported by Bouqbis et al. may be unique for the population studied, and again points to the fact that it is unlikely that the $+49 \mathrm{~A} / \mathrm{G}$ SNP alone is a causal variant [19]. The samples studied by Bouqbis et al. were derived from Agadir town in south Morocco, which is geographically near to West Africa, but far from Egypt [19].

Furthermore, the $+49 \mathrm{~A} / \mathrm{G}$ allele has been found to be associated with T1D in Mediterranean populations, which are related to the North African populations generally and to the Egyptian specifically. Therefore, further studies comparing North and West African populations may clarify differences in the pattern of association of the CTLA-4 gene region and further fine map the disease variant in CTLA4

In summary, a strong association of the $+49 \mathrm{~A} / \mathrm{G}$ SNP in the CTLA-4 gene with T1D was found in a sample of Egyptian origin. The pattern of association was distinct from that observed previously in other populations, providing further evidence to the clarification of demographic and disease associations of different CTLA-4 SNPs.

\section{Acknowledgements}

To Professor Dr. Ingo Hansmann and Dr. Monika Hagemann (Human Genetics and Medical Biology Institute - Medicine Faculty- Martin Luther University- Germany) for their technical assistance also for their critical discussion and review of the paper. This study was supported partially by the Diabetic Youth Care Association, DYCA-Egypt.

\section{References}

1. Jahromi MM, Eisenbarth GS (2006) Genetic determinants of type 1 diabetes across populations. Ann N Y Acad Sci 1079: 289-299.

2. Barrett JC, Clayton DG, Concannon P, Akolkar B, Cooper JD, et al. (2009) Genome-wide association study and meta-analysis find that over 40 loci affect risk of type 1 diabetes. Nat Genet 41: 703-707.

3. Pociot F, McDermott MF (2002) Genetics of type 1 diabetes mellitus. Genes Immun 3: 235-249.

4. Nisticò L, Buzzetti R, Pritchard LE, Van der Auwera B, Giovannini C, et al (1996) The CTLA-4 gene region of chromosome $2 q 33$ is linked to, and associated with, type 1 diabetes. Belgian Diabetes Registry. Hum Mol Genet 5: 1075-1080.

5. Vaidya B, Pearce $S$ (2004) The emerging role of the CTLA-4 gene in autoimmune endocrinopathies. Eur J Endocrinol 150: 619-626.

6. Alegre ML, Frauwirth KA, Thompson CB (2001) T-cell regulation by CD28 and CTLA-4. Nat Rev Immunol 1: 220-228.

7. Waterhouse P, Penninger JM, Timms E, Wakeham A, Shahinian A, et al (1995) Lymphoproliferative disorders with early lethality in mice deficient in Ctla-4. Science 270: 985-988.

8. Qu HQ, Bradfield JP, Grant SF, Hakonarson H, Polychronakos C, et al. (2009) Remapping the type I diabetes association of the CTLA-4 locus. Genes Immun 10: 27-32.

9. Van der Auwera BJ, Vandewalle CL, Schuit FC, Winnock F, De Leeuw IH, et al. (1997) CTLA-4 gene polymorphism confers susceptibility to insulin-dependent diabetes mellitus (IDDM) independently from age and from other genetic or immune disease markers. The Belgian Diabetes Registry. Clin Exp Immunol 110: $98-103$

10. Marron MP, Raffel LJ, Garchon HJ, Jacob CO, Serrano-Rios M, et al. (1997) Insulin-dependent diabetes mellitus (IDDM) is associated with CTLA-4 polymorphisms in multiple ethnic groups. Hum Mol Genet 6: 1275-1282.

11. Abe T, Takino H, Yamasaki H, Ozaki M, Sera Y, et al. (1999) CTLA4 gene polymorphism correlates with the mode of onset and presence of ICA512 Ab in Japanese type 1 diabetes. Diabetes Res Clin Pract 46: 169-175.

12. Takara M, Komiya I, Kinjo Y, Tomoyose T, Yamashiro S, et al. (2000) Association of CTLA-4 gene A/G polymorphism in Japanese type 1 diabetic patients with younger age of onset and autoimmune thyroid disease. Diabetes Care 23: 975-978.

13. Ihara K, Ahmed S, Nakao F, Kinukawa N, Kuromaru R, et al. (2001) Association studies of CTLA-4, CD28, and ICOS gene polymorphisms with type 1 diabetes in the Japanese population. Immunogenetics 53: 447-454.

14. Kikuoka N, Sugihara S, Yanagawa T, Ikezaki A, Kim HS, et al. (2001) Cytotoxic T lymphocyte antigen 4 gene polymorphism confers susceptibility to type 1 diabetes in Japanese children: analysis of association with HLA genotypes and autoantibodies. Clin Endocrinol (Oxf) 55: 597-603.

15. Ide A, Kawasaki E, Abiru N, Sun F, Kobayashi M, et al. (2004) Association between IL-18 gene promoter polymorphisms and CTLA-4 gene 49A/G polymorphism in Japanese patients with type 1 diabetes. J Autoimmun 22: 73 78.

16. Lee YJ, Huang FY, Lo FS, Wang WC, Hsu CH, et al. (2000) Association of CTLA4 gene A-G polymorphism with type 1 diabetes in Chinese children. Clin Endocrinol (Oxf) 52: 153-157.

17. Chistiakov DA, Savost'anov KV, Nosikov VV (2001)CTLA4 gene polymorphisms are associated with, and linked to, insulin-dependent diabetes mellitus in a Russian population. BMC Genet 2: 6 .

18. McCormack RM, Maxwell AP, Carson D, Patterson CC, Bingham A, et al (2001) Possible association between CTLA4 DNA polymorphisms and early onset type 1 diabetes in a UK population. Genes Immun 2: 233-235. 
Citation: Saleh HM, Koeleman B, Szénási G, Rosivall L, Hamar P (2013) Association of CTLA-4 Polymorphisms with Type 1 Diabetes in the Egyptian Population. J Diabetes Metab 4: 291. doi:10.4172/2155-6156.1000291

19. Bouqbis L, Izaabel H, Akhayat O, Pérez-Lezaun A, Calafell F, et al. (2003) Association of the CTLA4 promoter region $(-1661 \mathrm{G}$ allele) with type 1 diabetes in the South Moroccan population. Genes Immun 4: 132-137.

20. Haller K, Kisand K, Pisarev H, Salur L, Laisk T, et al. (2007) Insulin gene VNTR, CTLA-4 +49A/G and HLA-DQB1 alleles distinguish latent autoimmune diabetes in adults from type 1 diabetes and from type 2 diabetes group. Tissue Antigens 69: 121-127.

21. Korolija M, Renar IP, Hadzija M, Medvidović EP, Pavković P, et al. (2009) Association of PTPN22 C1858T and CTLA-4 A49G polymorphisms with Type 1 Diabetes in Croatians. Diabetes Res Clin Pract 86: e54-57.

22. Awata T, Kurihara S, litaka M, Takei S, Inoue I, et al. (1998) Association of CTLA-4 gene A-G polymorphism (IDDM12 locus) with acute-onset and insulindepleted IDDM as well as autoimmune thyroid disease (Graves' disease and Hashimoto's thyroiditis) in the Japanese population. Diabetes 47: 128-129.

23. Hayashi H, Kusaka I, Nagasaka S, Kawakami A, Rokkaku K, et al. (1999) Association of CTLA-4 polymorphism with positive anti-GAD antibody in Japanese subjects with type 1 diabetes mellitus. Clin Endocrinol (Oxf) 51: 793799

24. Larsen ZM, Kristiansen OP, Mato E, Johannesen J, Puig-Domingo M, et al. (1999) IDDM12 (CTLA4) on 2q33 and IDDM13 on 2q34 in genetic susceptibility to type 1 diabetes (insulin-dependent). Autoimmunity 31: 35-42.

25. Cinek O, Drevínek P, Sumník Z, Bendlová B, Kolousková S, et al. (2002) The CTLA4 +49 A/G dimorphism is not associated with type 1 diabetes in Czech children. Eur J Immunogenet 29: 219-222.

26. Mojtahedi Z, Omrani GR, Doroudchi M, Ghaderi A (2005) CTLA-4 +49 A/G polymorphism is associated with predisposition to type 1 diabetes in Iranians. Diabetes Res Clin Pract 68: 111-116.

27. Caputo M, Cerrone GE, Mazza C, Cédola N, Targovnik HM, et al. (2007) No evidence of association of CTLA-4 $-318 \mathrm{C} / \mathrm{T}, 159 \mathrm{C} / \mathrm{T}, 3$ ' STR and SUMO4 163 AG polymorphism with autoimmune diabetes. Immunol Invest 36: 259-270.

28. Angel B, Balic I, Santos JL, Codner E, Carrasco E, et al. (2009) Associations of the CTLA-4 polymorphisms with type 1 diabetes in a Chilean population: caseparent design. Diabetes Res Clin Pract 85: e34-36.

29. Lemos MC, Coutinho E, Gomes L, Bastos M, Fagulha A, et al. (2009) The CTLA4 +49 A/G polymorphism is not associated with susceptibility to type 1 diabetes mellitus in the Portuguese population. Int J Immunogenet 36: 193-195.
30. Celmeli F, Türkkahraman D, Özel D, Akçurin S, Yegin O (2013) CTLA-4 $(+49 A / G)$ polymorphism and type-1 diabetes in Turkish children. J Clin Res Pediatr Endocrinol 5: 40-43.

31. Todd JA, Mijovic C, Fletcher J, Jenkins D, Bradwell AR, et al. (1989) Identification of susceptibility loci for insulin-dependent diabetes mellitus by trans-racial gene mapping. Nature 338: 587-589.

32. Doyle EA, Weinzimer SA, Steffen AT, Ahern JA, Vincent M, et al. (2004 A randomized, prospective trial comparing the efficacy of continuous subcutaneous insulin infusion with multiple daily injections using insulin glargine, Diabetes Care 27: 1554-1558.

33. Report of a World Health Organization Consultation (2011) Use of glycated haemoglobin $(\mathrm{HbA} 1 \mathrm{c})$ in the diagnosis of diabetes mellitus. Diabetes Res Clin Pract 93: 299-309.

34. Dorman J (1997) Molecular epidemiology of insulin-dependent diabetes mellitus: WHO DiaMond Project. WHO DiaMond Molecular Epidemiology SubProject Group. Gac Med Mex 133: 151-154.

35. Miller SA, Dykes DD, Polesky HF (1988) A simple salting out procedure for extracting DNA from human nucleated cells. Nucleic Acids Res 16: 1215.

36. Purcell S, Cherny SS, Sham PC (2003) Genetic Power Calculator: design of linkage and association genetic mapping studies of complex traits. Bioinformatics 19: 149-150.

37. Dudbridge $F$ (2008) Likelihood-based association analysis for nuclear families and unrelated subjects with missing genotype data. Hum Hered 66: 87-98.

38. Bertell R (1975) An alternate method for calculating an odds ratio. J Med 6 $15-26$.

39. Dickson SP, Wang K, Krantz I, Hakonarson H, Goldstein DB (2010) Rare variants create synthetic genome-wide associations. PLoS Biol 8: e1000294.

40. Saleh HM, Rohowsky N, Leski M (2008) The CTLA4 -819 C/T and +49 A/G dimorphisms are associated with Type 1 diabetes in Egyptian children. Indian J Hum Genet 14: 92-98.

41. Kristiansen OP, Larsen ZM, Pociot F (2000) CTLA-4 in autoimmune diseases-a general susceptibility gene to autoimmunity? Genes Immun 1: 170-184.

42. Ueda H, Howson JM, Esposito L, Heward J, Snook H, et al. (2003) Association of the T-cell regulatory gene CTLA4 with susceptibility to autoimmune disease. Nature 423: 506-511. 